\title{
The Effect of Reading Ayatul Kursi on Water The Germination Lettuce Plant (Lactuca sativa L.)
}

\author{
N K Jannah \\ Islamic Building School of Jagad 'Alimussirry Surabaya, Indonesia \\ Email: nurdianak.j94@gmail.com
}

\begin{abstract}
Ayatul kursi is verse 255 of surah Baqarah of the Qur'an. Water can respond to words, images and sounds, so that affect the germination of lettuce plants. The purpose of this study is to describe the number of verses reciting the most optimal for germination of lettuce plant (Lactuca sativa L.). This research was conducted for 3 days, by giving different treatments. Control treatment on plastic bottle A without reading ayatul kursi. Plastic bottle B reading ayatul kursi 1 times. Plastic bottle $\mathrm{C}$ reading ayatul kursi 2 times. Plastic bottle D reading ayatul kursi 3 times. Plastic bottle E reading ayatul kursi 4 times. The result of the study showed that the most optimal with reading ayatul kursi 4 times which was $2.28 \mathrm{~cm}$. The effect of reading ayatul kursi is that the greater the number of readings, it can increase the length of germination lettuce plant.
\end{abstract}

Keywords: Ayatul kursi; germination; lettuce plant

\section{INTRODUCTION}

Water is one of the greatest gifts given by Allah SWT to humans, animals and plants. All living things in this world cannot live without water. Water is the main source of life. Almost all chemical reactions in life need water, so that if there is a deficiency or drought it can kill faster than other lack of nutrients. This fact can be proven that living things can only survive a few days without water, but different from when lacking in nutrients will survive longer which is around several weeks or months [1].

Water is a liquid that has no taste, color and smell. Water consists of hydrogen and oxygen bonds with the chemical formula, $\mathrm{H}_{2} \mathrm{O}$. Water can also answer the surrounding environment, agreeing this is evidenced by the research carried out obtained crystal water images using the response of words, images and sounds [2].

Ayatul kursi are the most magnificent in the Qur'an and contains the names of Allah.
Rasululloh, has explained that the greatest name of Allah is in the verse of the Qur'an, one of them is ayatul kursi. When ayatul kursi read to water will give a positive response. In addition, the verse of this chair is often used by the community because it will bring blessings and get protection from Allah SWT. To find out how influential this verse is, it was applied to the germination of lettuce plants. Ayatul kursi has a great position and a high degree because this verse contains the noblest case and the most important knowledge. This verse contains the attributes of Allah and the glorification and praise of Allah SWT [3].

Germination is the process of producing seeds to produce new plants. Seeds will germinate according to the appropriate environment. The process of adding a suitable temperature, amount of air, sufficient amount of oxygen, humidity and light [4]. Germination metabolism begins with the process of absorption of water by seeds, softening the seed coat and hydration of protoplasm. Then 
enzyme and cell activity occurs and the respiration rate increases in the seeds. After that, there is a breakdown of ingredients such as carbohydrates, fats and proteins into a form that is dissolved and translocated to a growing point [5].

Lettuce plant (Lactuca sativa L.) is a type of vegetable that has not been widely cultivated by the community, but in economic prospects are quite good. The demand for lettuce plant commodities continues to increase, among restaurants and hotels [6]. Based on data published by the Directorate of Nutrition of the Ministry of Health, the composition contained in every 100 grams of fresh weight of lettuce plant consists of $1.2 \mathrm{~g}$ of protein; $0.2 \mathrm{~g}$ of fat; 15 cal calories; $2.9 \mathrm{~g}$ carbohydrates; $22 \mathrm{mg} \mathrm{Ca} ; 25 \mathrm{mg} \mathrm{P}$; $0.5 \mathrm{Fe}$; $540 \mathrm{~g}$ of vitamin $\mathrm{A} ; 0.04 \mathrm{mg}$ of vitamin $\mathrm{B} ; 8$ $\mathrm{mg}$ of vitamin $\mathrm{C}$; and $94.8 \mathrm{~g}$ of water [7]. Lettuce plant can be planted in low or high land, optimal temperature for lettuce plant growth between $15-25^{\circ} \mathrm{C}$. Environmental conditions this will increase good growth. Many people choose to consume lettuce because it has the color, texture and aroma needed to add food to increase appetite [8].

Based on the background above, it is necessary to carry out research on the effect of reading water ayatul kursi on the germination lettuce plant (Lactuca sativa L.)

\section{METHOD}

\section{A. Place and time of research}

The research was conducted at Green house Islamic Building School of Jagad 'Alimussirry Surabaya. The study was conducted for 3 days.

\section{B. Preparation of planting media}

Prepare plastic cups, cotton, lettuce seeds and water. Lettuce seeds are soaked inside in water for 15 minutes, the cotton is put into a plastic cup of the same size, one plastic cup contains 5 lettuce seeds and labeled. Then the water is read ayatul kursi.

\section{Application}

Watering is every morning and evening, recorded the results of his observations.

\section{RESULT AND DISCUSSION}

In this study, it was carried out for 3 days using the number of verse recitations. Based on the results of observations that have been made on germination of lettuce plants, the results of observations are obtained in the table I.

Table I. The average length of germination lettuce plant after giving various of reading amounts ayatul kursi.

\begin{tabular}{c|c}
\hline $\begin{array}{c}\text { Number of reading } \\
\text { ayatul kursi }\end{array}$ & $\begin{array}{c}\text { Average length germination } \\
(\mathbf{c m})\end{array}$ \\
\hline Control & $1.02 \pm 0.93$ \\
\hline 1 & $1.28 \pm 0.96$ \\
\hline 2 & $1.08 \pm 0.85$ \\
\hline 3 & $2.00 \pm 0.54$ \\
\hline 4 & $2.28 \pm 0.65$ \\
\hline
\end{tabular}

Based on the table above, the following will be presented a histogram image of the length of the lettuce plant.

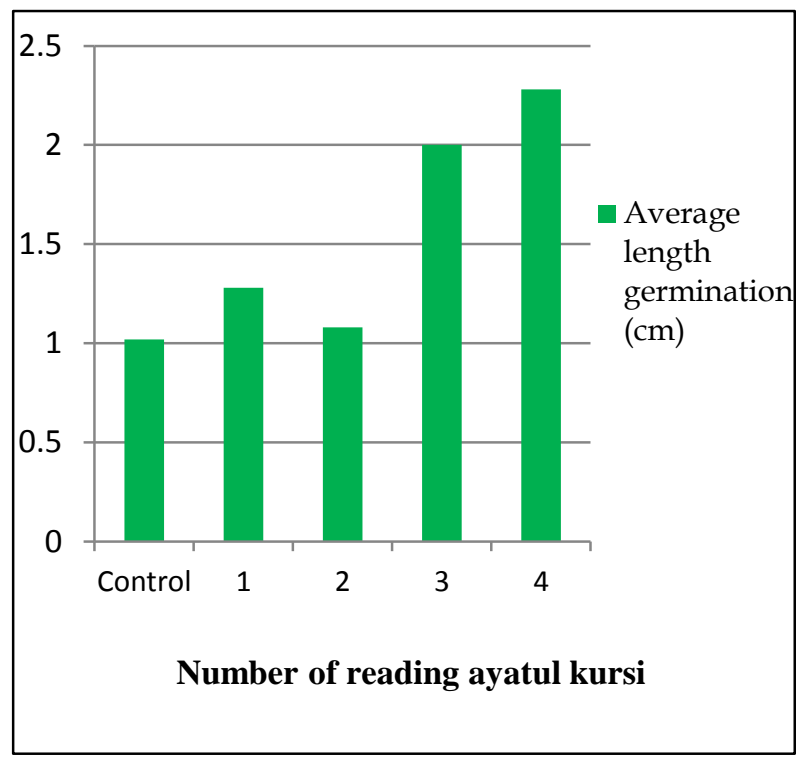

Figure 1. The effect of giving various amounts of reading ayatul kursi to germination of lettuce plants 
Based on Table 1. and Figure 1., it can be seen that in the number of 4 readings shows the optimal effect on germination of lettuce plants. This is due to the ayatul kursi contains the names of Allah, so that the more numbers are read, the higher the results. However, the number of reading ayatul kursi 2 shows a lower value than the number of reading ayatul kursi 1, because the content contained in water has the same content, so when applied to the seeds, it gives a response that is not much different.

Effect of reading water ayatul kursi on the germination lettuce plant (lactuca sativa $\mathrm{L}$.) his is because water can receive information from outside both the response by means of pictures and sounds. Ayatul kursi is a noble reading, so that when the water realizes that the word received brings good information, the water will form a very beautiful crystal [9].

Pratiwi [10] according the factors that influence the germination process consist of 2 , the internal factors and external factors. If there is germination that looks optimal development can be due to the hormones contained in the seeds do not run well, so that it can affect the metabolic process during the germination process.

\section{CONCLUSION}

There was a significant difference in the length of germination lettuce plant (Lactuca sativa L.) which was treated with various readings ayatul kursi, while the control treatment showed the lowest value. The most optimal number of readings on germination of lettuce plants (Lactuca sativa $\mathrm{L}$.) is the number of 4 readings with a value of $2.28 \mathrm{~cm}$.

\section{REFERENCES}

[1] P. S. Ritonga, “Air" Sebagai Sarana Peningkatan Imtaq (Integrasi Kimia dan Agama)," J. Sosial Budaya, vol. 8(2), pp. 267276, 2011.

[2] D. Radin, N. Lund, M. Emoto, and T. Kizu, "Effects of Distant Intention on Water Crystal
Formation: A Triple-Blind Replication, "J. of Scientific Exploration, vol. 00 no.0, 2008.

[3] F. Ilahi, "Dahsyatnya Keajaiban Ayat Kursi," Yogyakarta: Maktabah Al-Hanif, 2009.

[4] H. Purnobasuki, "Perkecambahan," 2011. [Accessed on February 22 ${ }^{\text {th }}, 2017$ : http://skp.unair.ac.id/repository/GuruIndonesi a/Perkecambahan_HeryPurnobasuki_237.pdf]

[5] A. R. Loveles,"Prinsip-prinsip Biologi Tumbuhan untuk Daerah Tropik, "Jakarta: Pustaka Utama. 1991.

[6] L. Zuhaida, E. Ambarwati, and E. Sulistyaningsih, "Petumbuhan dan Hasil Selada (Lactuca sativa L.) Hidroponik Diperkaya Fe, "Yogyakarta: Gadjah Mada University, 2009.

[7] E. Haryanto, S. Tina, R. Estu, "Sawi dan Selada, "Jakarta: Rineka Cipta. 2006.

[8] E. P. Ningsih, "Respon Penggunaan Media Tanam Pada Pembibitan Selada (Lactuca sativa L.), "J. Ilmu Pertanian dan Perikanan, vol. 3(2), pp. 111-116, 2014.

[9] R.T. Prodoningrum, "Molekul Air yang dibacakan ayat Al-Qur'an, “2015. [Accessed on February 22 2017 : http://miftahhabibi.abatasa.co.id/post/detail/45 881/molekul-air-yang-dibacakan-ayat-alquran].

[10] Pratiwi, "Biology, "Jakarta: Erlangga. 2006. 